\title{
$\$$ Research Square

\section{Characterization of ECM fungal community under three different vegetation restorations in iron tailing}

Wenxu Zhu ( $\square$ zhuwenxu.315@163.com )

Shenyang Agricultural University https://orcid.org/0000-0002-7367-3754

\section{Changjun Ding}

Chinese Academy of Forestry

Keye Zhu

Shenyang Agricultural University

\section{Weixi Zhang}

Chinese Academy of Forestry

Dejun Liang

Liaoning Provincial Poplar Institure

XiaoJiang Wang

Inner Mongolia Academy of Forestry Sciences

Aiping Li

Inner Mongolia Academy of Forestry Sciences

Xiaohua Su

Chinese Academy of Forestry

\section{Research Article}

Keywords: iron tailings, ectomycorrhizal fungi, revegetation, Robinia pseudoacacia L, soil characteristics

Posted Date: January 21st, 2022

DOI: https://doi.org/10.21203/rs.3.rs-1208979/v1

License: (c) (i) This work is licensed under a Creative Commons Attribution 4.0 International License.

Read Full License 


\section{Abstract}

Vegetation restoration is an effective method to improve the ecological environment of mine tailings, which has a profound impact on the potential ecological functions of soil fungal communities, yet little is known about its beneficial effect on soil ectomycorrhizal fungal community. In this study, the responses of soil characteristics and soil ectomycorrhizal fungal community diversity and structure to different revegetation, as well as the contribution of soil factors to soil ectomycorrhizal community were investigated in Liaoning Province, China. As we anticipated, the vegetation restoration significantly improved soil nutrients. What's more, compared to PKSZ and PSC, RPL could better improve soil TC, TN, TP, and AP. In addition, soil ectomycorrhizal community diversity in RPL was greater than PKSZ and PSC. NMDS analyses indicated that soil ectomycorrhizal community significantly differed depending on different revegetation types. Thus, these results indicated that RPL could be a suitable species for the revegetation of iron mine tailings. The experiment provided theoretical basis for evidence for ecological restoration of iron mine tailings using local plant species.

\section{Introduction}

China is one of the world's most biodiverse countries and also a large exporter of commodities such as iron ore. Iron mining activities have important economic and social benefits, despite having a significant impact on the landscape (Skirycz et al., 2014), soil basic characteristics and soil microbial community, as it not only dramatically occupy and destroy a large amount of land, produce large amount of mine tailings, influence soil pH value and soil structure, decrease plant water availability, reduce soil organic matter stock (Oliveira et al., 2014), threat to the biodiversity and result in compromised ecosystem functions, but also pollute air environment and affect human health for a long time (Zhang et al., 2010; Li, 2006). From a long-term perspective of sustainable use of land resources and protection of the ecological environment, there is an urgent need for a feasible way to restore the degraded ecosystems (Wang et al., 2017).

In areas degraded by iron mining, natural regeneration is slow and often impossible (Silva et al., 2006) due to the physical and chemical characteristics of the substrate (González-Alcaraz and van Gestel 2017), such as poor physical structure (Silva et al., 2006), alkaline pH (Wu et al., 20206), low water retention capacity, nutrient (N, P) deficiency (Wu et al., 2018), and high metal stress (López-Orenes et al., 2017; Wang et al., 2017). In addition, in degraded iron ore areas with the characteristic of low nutrient concentration and high density of the substrate, artificial vegetation restoration is a huge challenge (Rios et al., 2021; Wang et al., 2017). In recent years, the recovery of iron-ore mined areas can be achieved through a variety of hard engineering techniques, and phytoremediation has been considered to be a more efficient, economical, and environmentally sustainable remediation strategy compared to physical and chemical methods (Wang et al., 2017; Skirycz et al., 2014), as it could preserve the soil resource, improve soil structure, physico- and bio-chemical properties, biodiversity patterns, ecosystem functioning (Gastauer et al., 2019), soil microbial diversity (Touceda-Gonzalez et al., 2017; Xue et al., 2015), ultimately creating self-sustaining vegetation communities. Given that, the selected species for revegetation 
purposes must be able to thrive under these multi-stress scenarios (Peng et al., 2019), and the selection of suitable plants species is the first step for restoration of mine tailings.

In previous studies, many herbaceous (Fernandez et al., 2017; Heckenroth et al., 2016; Mahdavian et al., 2017) and woody plants (Siebielec et al., 2018; Luo et al., 2019), such as Paspalum densum, Setaria parviflora (Rios et al. 2017; Araújo et al., 2015), and Robinia Pseudoacacia (Deng et al., 2020a; Deng et al., $2020 \mathrm{~b}$ ), have proven to be potential candidates for revegetating iron-ore mined areas. In addition, the integration of soil biological indicators with chemical and physical indicators is an important factor in the evaluation of soil quality and the recovery process (Silva et al., 2018). A number of mine tailing reclamation findings have emphasized a strong association between the establishment of a stable plant community and the abundance and composition of soil microbiota (Deng et al., 2020a; Asmelash et al., 2016; Mendez et al., 2008), mainly focusing on the bacteria (Deng et al., 2020a), fungi (Deng et al., 2020b), and arbuscular mycorrhizal fungi (AMF) (Jude et al., 2021; Wu et al., 2020; Prado et al., 2019). However, the links between plant taxa succession and their associated ectomycorrhizal fungal communities remain to be addressed.

Ectomycorrhizal fungi have many beneficial ecological effects on host plants. They can not only improve plant roots ability to absorb soil moisture and nutrients (van der Heijden and Hartmann, 2016; Michalis et al., 2013; Augé et al., 2007), enhance plant photosynthesis (Gong et al., 2013), but also directly synthesize or induce host plants to produce a variety of hormones (Fitze et al., 2005), promote the secretion of soil proteins from host plants to participate in the formation and stabilization of soil aggregates (Veresoglou et al., 2011) in the process of symbiosis with host plants, thereby promoting plant survival, growth and development, enhancing plant adaptation to various environmental stresses, driving critical ecosystem functions and promoting the restoration and reconstruction of degraded ecosystem (Silva et al., 2018; Teixeira et al., 2017; Vieira et al., 2017; Leal et al., 2016). Considering the importance of ECM fungi in soil ecosystem, it is important to understand the composition and diversity of ECM fungal communities at tailing sites, for the sake of mined land rehabilitation.

Iron ore in China is widespread and relatively concentrated. At present, there are five major areas of concentrated distribution of iron ore reserves in China, among which Anshan-Benxi iron mine wasteland in the northeast covers the largest area. Iron ore mining has made a great contribution to the regional economic development (Wilson, 2012), however, serious environmental problems are caused by iron mining in China. Furthermore, with the implementation of national policies related to ecological civilization construction, it is imperative to carry out reasonable mine ecological restoration in AnshanBenxi iron mined area to ensure the harmonious development of society, economy and environment. Therefore, the construction of green mines and ecological restoration should be actively promoted in the process of mining development (Sheoran et al., 2010). At present, considerable researches mainly focused on the vegetation restoration measures and technique (Zhang, 2018; Zhang et al., 2018), as well as the effects of ecological restoration on soil macro-animal communities (Liu et al., 2009) and soil microorganisms (Deng et al., 2020a) in iron mining areas of Liaoning Province. However, information as to the ECM fungal communities associated with different revegetation is insufficient and therefore 
needed. Therefore, the objective of this study was to investigate whether the three native woody plants, including Pinus koraiensis Sieb. et Zucc., Robinia pseudoacacia L, Populus simonii Carr, can improve the soil basic characteristics and soil ECM fungal community after 15 years of aided phytostabilization under field conditions. It is hypothesized that 1 ) vegetation restoration could promote the accumulation of soil nutrients; 2) vegetation restoration could clearly shift soil ECM fungal community diversity and composition; 3 ) along with the restoration of vegetation, the remarkable abiotic changes were the accumulation of soil nutrients, which affect the shifts of ECM fungal communities. The findings of this study will be beneficial for the selection of suitable vegetation types to accelerate the vegetation restoration process in iron mine tailing.

\section{Materials And Methods}

\section{Site information}

The study area is located in Dengta City, Liaoyang City, Liaoning province, China (40.74 N, 122.86 E), which is classified as north temperate continental climate with the feature of warm spring, hot summer, cool autumn, cold winter, four distinct seasons, rain hot season, sufficient sunshine. The annual average temperature is $8.8^{\circ} \mathrm{C}$, and the annual average frost-free period is 171 days. The rainfall is abundant, mainly in summer, with an average annual total rainfall of about $686.0 \mathrm{~mm}$. Pinus tabuliformis, Larix gmelinii, Pinus koraiensis, Robinia pseudoacacia, Populus simonii, and Ulmus pumila are the main vegetation.

\section{Sample collection}

The details of study area and plot setting were described in the study from Deng et al. (2020a). Rhizosphere soil from Pinus koraiensis Sieb. et Zucc. (PKSZ), Robinia pseudoacacia L (RPL), Populus simonii Carr (PSC) in revegetated iron-mining sites were collected in June 2019. Four plots $(20 \times 20 \mathrm{~m})$ were randomly established in each site as repetitions, with a distance of approximately $50 \mathrm{~m}$. In each plot, 9 plants with well growth and consistent growth were randomly selected, then large pieces of sand and other debris on the surface were removed. Fine root samples and soil samples were collected at a depth of 0-30 cm, and the rhizosphere soil of 9 plants at the same plot were collected, mixed as one sample, then placed in a ziplock bag and taken back to the laboratory in ice boxes, resulting in 12 samples. The fresh soil samples were divided into two parts. One part removed stone and plant residues was passed through a 2-mm sieve and immediately put into $2 \mathrm{ml}$ centrifugal tube and stored at $-80^{\circ} \mathrm{C}$ until DNA extraction, and the other part was air-dried and sieved for determination of soil characteristics.

\section{The determination of soil parameters}

The soil $\mathrm{pH}$ was assayed in soil: water $(\mathrm{w} / \mathrm{v})$ of $1: 2.5 \mathrm{H}_{2} \mathrm{O}$ suspensions following shaking of the samples for 30 min, using a pH meter (Mettler Toledo pH (FE20)). The contents of soil total carbon (TC) and total nitrogen (TN) were determined by an elemental analyzer (Euro Vector EA3000). The concentrations of total phosphorus (TP) and available phosphorus (AP) were measured by spectrophotometer (UV-9000S) 
after digestion with $\mathrm{H}_{2} \mathrm{SO}_{4}-\mathrm{HClO}_{4}$ and extracted with $0.5 \mathrm{~mol} \cdot \mathrm{L}^{-1} \mathrm{NaHCO}_{3}$, respectively. The available $\mathrm{K}$ content was determined by atomic absorption spectrometry using $1.0 \mathrm{~mol} \cdot \mathrm{L}^{-1} \mathrm{NH}_{4} \mathrm{OAc}$ as extractant. The concentration of available $\mathrm{N}$ was measured by the alkali solution diffusion method.

\section{DNA extraction}

The DNA was extracted from $0.5 \mathrm{~g}$ of soil using the FastDNA SPIN Kit (MP Biomedicals, Santa Ana, CA, USA), according to the manufacturer's instructions. Amplification of the nuclear ribosomal DNA from the ITS1 region was performed using the fungal specific primer pair ITS1F and ITS2 (Caban et al., 2018; Nottingham et al., 2018; Deng et al., 2021). The first PCR $(25 \mu$ total per reaction) contained $2 \mu$ l of dNTPs (2.5 mM), $2 \mu$ l of DNA Template (40-50 ng), $8.75 \mu$ of $\mathrm{ddH}_{2} \mathrm{O}, 1 \mu \mathrm{l}(10 \mathrm{uM})$ of forward and reverse primer, respectively; $5 \mu$ l of Q5 reaction buffer ( $5 \times$ ) and Q5 High-Fidelity GC buffer ( $5 \times)$, severally; $0.25 \mu \mathrm{l}(5 \mathrm{U} / \mu \mathrm{l})$ of Q5 High-Fidelity DNA Polymerase (Deng et al., 2020). Following the initial denaturation at $95^{\circ} \mathrm{C}$ for five minutes; 23 cycles of $95^{\circ} \mathrm{C}$ for $30 \mathrm{~s}, 58^{\circ} \mathrm{C}$ for $90 \mathrm{~s}, 72{ }^{\circ} \mathrm{C}$ for $4.5 \mathrm{~min}$; then final elongation at $72{ }^{\circ} \mathrm{C}$ for 10 min. The amplicons were purified and quantified using Agencourt AMPure Beads (Beckman Coulter, Indianapolis, IN) and PicoGreen dsDNA Assay Kit (Invitrogen, Carlsbad, CA, USA). PCR products for sequencing were carried out using an Illumina NovaSeq 6000 sequencing platform at Shanghai Personal Biotechnology Co., Ltd, Shanghai, China. The high-throughput sequencing raw data of fungi were uploaded in the NCBI database with the SRA accession number of PRJNA776422.

\section{Data analysis}

Soil characteristics and soil ECM fungal community diversity among different samples were subjected to ANOVA and means were compared by Tukey's test $(p<0.05)$. Venn diagram was used to analyze the shared and unique OTUs among different samples in Rstudio with the package of vegan. NMDS was used to compare the difference of ECM fungal beta diversity and carried out using R studio with the packages of vegan, permute, and lattice. LEfSe analysis, namely LDA Effect Size analysis, can find the species with significant differences in abundance between groups (i.e. Biomaker). Spearman's correlation coefficients between soil basic characteristics and ECM fungal community diversity and composition were analyzed using SPSS 20.0. The effects of experimental variables on ECM fungal communities in roots were analyzed by canonical correspondence analysis (CCA) using the CANOCO 5.10 software package.

\section{Results}

\section{Soil characteristics}

The concentrations of soil TC $(\mathrm{F}=8.71, P=0.01), \mathrm{TN}(\mathrm{F}=6.21, P=0.02), \mathrm{C} / \mathrm{N}(\mathrm{F}=12.55, P=0.00), \mathrm{AN}(\mathrm{F}$ $=13.34, P=0.00), \operatorname{TP}(\mathrm{F}=6.00, P=0.02), \mathrm{AP}(\mathrm{F}=20.52, P=0.00)$, and AK $(\mathrm{F}=6.59, P=0.02)$ differed significantly among PKSZ, RPL, and PSC, however, the soil pH existed no significant difference $(F=2.13$, $P=0.18$ ) (Table 1). RPL hold the highest contents of TC, TN, TP, and AP with $5.71 \mathrm{~g} / \mathrm{kg}, 0.74 \mathrm{~g} / \mathrm{kg}, 2.89$ 
$\mathrm{g} / \mathrm{kg}$, and $20.22 \mathrm{mg} / \mathrm{kg}$, respectively, while, PSC hold the highest AK content with $108.98 \mathrm{mg} / \mathrm{kg}$ (Table 1). Soil $\mathrm{pH}, \mathrm{TC}, \mathrm{TN}$, and TP in unrestored area were $8.17,1.30 \mathrm{~g} / \mathrm{kg}, 0.36 \mathrm{~g} / \mathrm{kg}$, and $1.03 \mathrm{~g} / \mathrm{kg}$ (Deng et al., 2020a).

Table 1

Differences in soil characteristics among PKSZ, RPL, and PSC. PKSZ:

Pinus koraiensis Sieb. et Zucc., RPL: Robinia pseudoacacia L., PSC:

Populus simonii Carr. Average value \pm standard error $(n=12)$. TC: total carbon, TN: total nitrogen, $\mathrm{C} / \mathrm{N}: \mathrm{C}$ to $\mathrm{N}$ ration, $\mathrm{AN}$ : available nitrogen,

TP: total phosphorus, AP: available phosphorus, AK: available potassium. Different capital letters in same row indicated the significant difference at 0.01 level, and different lowercase letters in same row indicated the significant difference at 0.05 level.

\begin{tabular}{|llllll|}
\hline & PKSZ & RPL & PSC & F & P \\
\hline $\mathrm{pH}$ & $7.18 \mathrm{aA}$ & $6.84 \mathrm{aA}$ & $7.00 \mathrm{aA}$ & 2.13 & 0.18 \\
\hline $\mathrm{TC}(\mathrm{g} / \mathrm{kg})$ & $3.23 \mathrm{bA}$ & $5.71 \mathrm{aA}$ & $5.48 \mathrm{aA}$ & 8.71 & 0.01 \\
\hline $\mathrm{TN}(\mathrm{g} / \mathrm{kg})$ & $0.49 \mathrm{bA}$ & $0.74 \mathrm{aA}$ & $0.64 \mathrm{abA}$ & 6.21 & 0.02 \\
\hline $\mathrm{C} / \mathrm{N}$ & $6.64 \mathrm{bB}$ & $7.66 \mathrm{abAB}$ & $8.64 \mathrm{aA}$ & 12.55 & 0.00 \\
\hline $\mathrm{AN}(\mathrm{mg} / \mathrm{kg})$ & $25.65 \mathrm{bB}$ & $38.92 \mathrm{aAB}$ & $46.43 \mathrm{aA}$ & 13.34 & 0.00 \\
\hline $\mathrm{TP}(\mathrm{g} / \mathrm{kg})$ & $2.26 \mathrm{bA}$ & $2.89 \mathrm{aA}$ & $2.38 \mathrm{abA}$ & 6.00 & 0.02 \\
\hline AP $(\mathrm{mg} / \mathrm{kg})$ & $14.89 \mathrm{bB}$ & $20.22 \mathrm{aA}$ & $13.30 \mathrm{bB}$ & 20.52 & 0.00 \\
\hline AK $(\mathrm{mg} / \mathrm{kg})$ & $69.88 \mathrm{bA}$ & $94.75 \mathrm{abA}$ & $108.98 \mathrm{aA}$ & 6.59 & 0.02 \\
\hline
\end{tabular}

\section{Sequencing and OTUs}

A total of 779, 651 fungal sequences (reads) were obtained by high-throughput amplification sequencing. After filtering, denoising, merging, removing chimera, and nonsingleton, 659, 453 (54, 955 per sample) high quality sequences remained in the dataset, which were clustered into 1,172 amplicon sequence variants (ASV) (Fig. 1). As the sequencing depth increased, the rarefaction curves for evaluating the observed_species per sample universally tended to be saturation, demonstrating that the number of sequences was sufficient (Fig. S1). The number of ASVs of PKSZ, RPL, and PSC was 479, 697, and 356, respectively, and the number of ASVs shared by PKSZ, RPL, and PSC was 97 (Fig. 1).

\section{Ectomycorrhizal fungal diversity}

Ectomycorrhizal fungal Chao1 index $(F=17.98, P<0.01)$, Pielou_e index $(F=9.44, P<0.01)$, Shannon index $(F=15.54, P<0.01)$, and Observed_species $(F=27.37, P<0.01)$ differed obviously among PKSZ, RPL, and PSC (Fig. 2). In addition, the mean Chao1 index, Pielou_e index, Shannon index, and Observed_species were even greater in RPL than PKSZ and PSC with 331.96, 0.72, 5.99, and 314.35, severally (Fig. 2). Neither Goods_coverage ( $F=0.08, P=0.92)$ nor Simpson index $(F=4.20, P=0.05)$ of ECM fungi in roots of PKSZ, RPL, and PSC differed distinctly (Fig. 2). Ectomycorrhizal fungal Chao1 index $(r=0.59, p<0.05)$ and Observed_species $(r=0.60, p<0.05)$ increased with the increase of TP 
(Table 2). Chao1 index $(r=0.76, p<0.01)$, Observed_species $(r=0.78, p<0.01)$, Pielou_e index $(r=0.64, p$ $<0.05)$, and Shannon index $(r=0.70, p<0.05)$ of ECM fungal communities inhabiting the roots increased with the increase of soil AP (Table 2).

\section{Table 2}

The relationships between soil characteristics and ectomycorrhizal fungal diversity $(\mathrm{n}=$ 12). * $P<0.05$, ** $P<0.01$. TC: total carbon, $T N$ : total nitrogen, $C / N$ : $C$ to $N$ ration, $A N$ : available nitrogen, TP: total phosphorus, AP: available phosphorus, AK: available potassium.

\begin{tabular}{|lcccccccc|}
\hline & PH & TC & TN & C/N & AN & TP & AP & AK \\
\hline Chao1 index & -0.31 & 0.27 & 0.44 & -0.16 & -0.03 & $\mathbf{0 . 5 9 ^ { * }}$ & $\mathbf{0 . 7 6 ^ { * * }}$ & -0.10 \\
\hline Goods_coverage & -0.03 & 0.09 & 0.16 & -0.07 & -0.03 & -0.10 & 0.03 & 0.07 \\
\hline Observed_species & -0.32 & 0.29 & 0.48 & -0.17 & -0.04 & $\mathbf{0 . 6 0 ^ { * }}$ & $\mathbf{0 . 7 8 ^ { * * }}$ & -0.10 \\
\hline Pielou_e index & -0.08 & 0.24 & 0.46 & -0.30 & -0.25 & 0.20 & $\mathbf{0 . 6 4 ^ { * }}$ & -0.32 \\
\hline Shannon index & -0.14 & 0.25 & 0.48 & -0.29 & -0.20 & 0.31 & $\mathbf{0 . 7 0}$ & -0.27 \\
\hline Simpson index & 0.02 & 0.16 & 0.35 & -0.30 & -0.35 & 0.01 & 0.44 & -0.49 \\
\hline
\end{tabular}

\section{Ectomycorrhizal fungal community composition}

A total of 12 phyla, 38 classes, 395 genus, and 575 species were identified in our study. The dominant fungal groups were Ascomycota, Basidiomycota, and Mortierellomycota at the phylum level, accounting for $99.43 \%$ (Fig. 3A). Agaricomycetes, Pezizomycetes, Sordariomycetes, Eurotiomycetes, Dothideomycetes, Mortierellomycetes, Leotiomycetes, and Tremellomycetes were the dominant fungal groups at the class level (Fig. S2A). At the genus level, the fungal groups with the average relative abundance more than 3.5\% were Hebeloma, Geopora, Sebacina, Tomentella, Penicillium, Fusarium, Metarhizium, Mortierella, Pulvinula, and Clavulina (Fig. 3B). At the species level, the fungal groups with the average relative abundance more than $2.0 \%$ were Hebeloma_mesophaeum, Geopora_arenicola, Clavulina_cinerea, Cenococcum_geophilum, Tomentella_ellisii, Gibberella_baccata, and Mortierella_alpina (Fig. S2B).

The NMDS (stress $=0.062$ ) demonstrated that ectomycorrhizal fungal community composition clearly differed among PKSZ, RPL, and PSC especially along NMDS1 (Fig. 5). The biomarkers in RPL were Ascomycota (74.72\%), Glomeromycota (0.94\%), Mortierellomycota (10.64\%), Eurotiomycetes (18.04\%), Leotiomycetes (2.66\%), Sordariomycetes (42.34\%), Tremellomycetes (3.52\%), Penicillium $(10.71 \%)$, Fusarium (16.11\%), Metarhizium (6.36\%), Mortierella (10.64\%), Gibberella (7.01\%), and Didymella (3.34\%) (Fig. 4). The biomarkers in PKSZ were Pezizomycetes (15.68\%), Geopora (22.55\%), Suillus (5.52\%), Pulvinula (12.71\%), and Cenococcum (9.25\%) (Fig. 4). The biomarkers in PSC were Basidiomycota (74.67\%), Agaricomycetes (25.925), Laccaria (4.41\%), Hebeloma (19.29\%), Inocybe (3.47\%), Sebacina (20.31\%), Tomentella (9.70\%), and Clavulina (10.26\%), and Tuber (9.45\%) (Fig. 4). 


\section{Contribution of soil properties to ectomycorrhizal fungal community composition}

For the ectomycorrhizal fungal community at the phylum level, all the eight soil characteristics explained $99.9 \%$ of the variance, with axis 1 explaining $82.40 \%$ of the variance and axis 2 explaining $16.60 \%$ (Fig. $6 \mathrm{~A})$. For the fungal community at the genus level, all the eight soil characteristics explained $65.0 \%$ of the variance (Fig. 6B), with axis 1 explaining $40.10 \%$ of the variance and axis 2 explaining $24.90 \%$ (Fig. 6B). Notably, the concentration of AP in soil was positively correlated with Mortierellomycota $(r=0.68, p<$ $0.05)$ and Glomeromycota $(r=0.59, p<0.05)$. Aphelidiomycota was significantly positive correlation with the concentration of soil TN $(r=0.59, p<0.05)$, TP $(r=0.77, p<0.01)$, and AP $(r=0.90, p<0.01)$. While, Mortierellomycota $(r=-0.73, p<0.01)$, Glomeromycota $(r=0.65, p<0.05)$, and Aphelidiomycota $(r=-0.75$, $\mathrm{p}<0.01)$ decreased with the increase of soil pH (Table 3 ). 
Table 3

The relationship between soil basic characteristics and ectomycorrhizal fungal community composition. $(n=12)$. ${ }^{*} \mathrm{P}<0.05$, $* * \mathrm{P}<0.01$. TC: total carbon, $\mathrm{TN}$ : total nitrogen, $\mathrm{C} / \mathrm{N}$ : $\mathrm{C}$ to $\mathrm{N}$ ration, AN: available nitrogen, TP: total phosphorus, AP: available phosphorus, AK: available potassium.

\begin{tabular}{|c|c|c|c|c|c|c|c|c|}
\hline & $\mathrm{pH}$ & TC & TN & $\mathrm{C} / \mathrm{N}$ & AN & TP & AP & AK \\
\hline Ascomycota & -0.17 & -0.12 & 0.01 & -0.52 & -0.40 & -0.11 & 0.22 & $-0.58^{*}$ \\
\hline Basidiomycota & 0.47 & -0.07 & -0.24 & 0.34 & 0.29 & -0.15 & -0.47 & 0.52 \\
\hline Mortierellomycota & $-0.73^{\star *}$ & 0.11 & 0.29 & -0.28 & -0.35 & 0.48 & $0.69^{*}$ & -0.53 \\
\hline Glomeromycota & $-0.65^{*}$ & 0.29 & 0.39 & -0.06 & -0.13 & 0.30 & $0.59^{*}$ & -0.34 \\
\hline \multirow[t]{2}{*}{ Aphelidiomycota } & $-0.75^{* *}$ & 0.49 & $0.59^{*}$ & 0.15 & 0.27 & $0.77^{\star \star}$ & $0.90^{* *}$ & 0.03 \\
\hline & $\mathrm{pH}$ & $\mathrm{TC}$ & $\mathrm{TN}$ & $\mathrm{C} / \mathrm{N}$ & AN & TP & AP & AK \\
\hline Hebeloma & 0.55 & $-0.78^{* *}$ & $-0.81^{\text {** }}$ & -0.46 & -0.33 & -0.28 & -0.37 & -0.05 \\
\hline Geopora & $0.75^{* *}$ & $-0.65^{*}$ & $-0.69^{*}$ & -0.43 & -0.41 & $-0.69^{*}$ & $-0.64^{*}$ & -0.21 \\
\hline Sebacina & 0.51 & -0.27 & -0.40 & 0.16 & 0.04 & -0.41 & $-0.76^{* *}$ & 0.14 \\
\hline Tomentella & $0.79^{* \star}$ & -0.17 & -0.29 & 0.05 & 0.00 & $-0.74^{* *}$ & $-0.74^{* *}$ & 0.25 \\
\hline Penicillium & -0.57 & 0.18 & 0.38 & -0.36 & -0.14 & 0.13 & 0.43 & -0.28 \\
\hline Fusarium & $-0.68^{*}$ & 0.29 & 0.43 & -0.22 & -0.17 & 0.42 & $0.61^{*}$ & -0.51 \\
\hline Metarhizium & $-0.61^{*}$ & -0.24 & -0.06 & -0.48 & $-0.58^{*}$ & 0.55 & $0.77^{* *}$ & $-0.62^{*}$ \\
\hline Mortierella & $-0.73^{* *}$ & 0.11 & 0.29 & -0.28 & -0.35 & 0.48 & $0.70^{*}$ & -0.53 \\
\hline Pulvinula & 0.57 & $-0.61^{*}$ & $-0.63^{*}$ & $-0.64^{*}$ & $-0.68^{*}$ & $-0.67^{*}$ & -0.51 & -0.47 \\
\hline Clavulina & $0.63^{*}$ & 0.28 & 0.07 & 0.44 & 0.46 & -0.53 & $-0.60^{*}$ & $0.70^{*}$ \\
\hline
\end{tabular}

At the genus level, soil fungal community composition was driven by soil properties (Table 3 ). The relation abundance of Hebeloma $(r=-0.78, p<0.01 ; r=-0.81, p<0.01)$ and Geopora $(r=-0.65, p<0.05 ; r=$ $-0.69, p<0.05)$ declined with the increase of TC and TN. There were high correlation coefficients present between AP and Geopora $(r=-0.64, p<0.05)$, Sebacina $(r=-0.76, p<0.01)$, Tomentella $(r=-0.74, p<$ $0.01)$, Fusarium $(r=0.61, p<0.05)$, Metarhizium $(r=0.77, p<0.01)$, Mortierella $(r=0.70, p<0.05)$, Clavulina $(r=-0.60, p<0.05)($ Table 3$)$.

\section{Discussion}


In present study, it was found that the soil nutrient contents increased significantly after 6 years of vegetation restoration in Anshan-Benxi iron mined area, in Liaoning Province, indicating that the implementation of ecological engineering was beneficial soil carbon sequestration, which is consistent with other studies (Hu et al., 2018; Hu et al., 2021; Zhang et al., 2021). On the one hand, no human disturbance can promote the formation of soil aggregates, thereby improving the SOC holding capacity. On the other hand, the increase in litter and root exudates after vegetation restoration increases the source of carbon input (Hong et al., 2021). It follows that the decrease of organic carbon mineralization and the increase of carbon input sources were the main reasons for the increase of SOC after vegetation restoration. Also, significant differences in the concentrations of soil TC, TN, C/N, AN, TP, AP, and AK differed significantly among PKSZ, RPL, and PSC (Table 1), which were highly similar to those reported by (hang et al. (2014). What's more, compared to PKSZ and PSC, RPL could better improve soil TC, TN, TP, and AP (Table 1), which was consistent with previous studies demonstrated that broadleaf forest could improve soil nutrients than coniferous forest (Deng et al., 2019a; Deng et al., 2019b). As we all know, the turnover of litter and fine roots is the main way of soil organic matter input, and the content of organic matter can affect the process of nitrogen transformation and accumulation. The relatively high soil organic matter and total nitrogen content of RPL may be related to factors such as higher litter content such as litter and stronger root replacement. Moreover, rhizobium related to the roots of Robinia pseudoacacia can fix nitrogen in the atmosphere and enrich soil nitrogen (Li et al., 2019).

\section{Responses of soil ectomycorrhizal fungal community diversity and composition to different revegetation}

An increasing body of research has shown that soil microorganisms are more sensitive than soil characteristics and can rapidly respond to environmental changes (Muñoz-Rojas et al., 2016). Soil microbial biomass, community diversity and composition as well as function are potential biological indicators of soil quality (Dinesh and Chaudhuri, 2013), which are applied to monitor the restoration of soil ecosystem functions during the restoration process in different degraded ecosystems (Sun et al., 2016; Yu et al., 2016). In present study, we compared the difference of soil ectomycorrhizal fungal community diversity and composition among three different vegetation restoration types, and linked the changes in the microbial combination with the soil properties.

Vegetation restoration and reconstruction regulate the interaction between microbial community and forest development, which is mainly manifested in the dynamic changes of microbial diversity and structure (Chanthorn et al., 2017). Our findings generally suggested that soil ectomycorrhizal fungal community diversity varied with vegetation restoration, and RPL hold the highest ectomycorrhizal fungal Chao1 index, Pielou_e index, Shannon index, and Observed_species (Fig. 2). This finding is coherent with the results of Deng et al. (2020a, 2020b). Soil microorganisms participate in a series of soil biochemical processes, which are closely related to the conversion of soil organic carbon (Rallage et al., 2021). In the process of vegetation restoration, a large amount of exogenous carbon entering the soil will be decomposed by soil carbon degrading enzymes to release low-molecular-weight sugars, providing important carbon and energy sources for microbial growth and metabolism (Davidson et al., 2004), thereby increasing soil microbial community diversity. 
Soil ectomycorrhizal fungal diversity reveals that the revegetation process plays an important role in the development of the microbial community composition. The results showed that overall ectomycorrhizal fungal community structure differed significantly among three different vegetation (Fig. 5), which supported our second hypothesis, confirming previous results which showed that ECM community structures may be directly impacted by their host (Sugiyama et al., 2021; Rosinger et al., 2018; van der Linde et al., 2018; Scheibe et al., 2015; Urbanová et al., 2015; Saitta et al., 2018; Molina and Horton, 2015). Differences in soil microbiome among different samples were mainly caused by the plant community, as observed in other mining site under a revegetation program (Vieira et al., 2018). These results confirmed that different components of the root microbiome can be complementary in the acquisition of essential and limiting nutrients in the ecosystem (de Quadros et al., 2016; Casazza et al., 2017).

In our study, the predominant ectomycorrhizal fungal group was Ascomycota, which was consistent with previous study (Guo et al., 2020). Ascomycota were detected in all sites, which degrade cellulose and more complex carbohydrates in the litter (Schoch et al., 2006) adapt to nutrient-poor and dry habitats (Ruibal et al., 2009). The predominance of the Ascomycota phylum, followed by Basidiomycota, is common in forests (Rosales-Castillo et al., 2018; Vieira et al., 2018). This information suggests that PKSZ, RPL, and PSC areas are recovering their ecosystem functions. The predominance of certain fungi genera in the soil interacting with certain plant species can ensure functional redundancy in different ecological contexts (Louca et al., 2018). Russula, Cortinarius, Tomentella, Tuber were the predominant ectomycorrhizal fungal groups of Quercus liaotungensis from Dongling Mountain, Beijing (Wang et al., 2012). In addition, Russula was the core ectomycorrhizal fungal group of Quercus variabilis in Taihang Mountain gneiss area (Wei et al., 2018). The main ectomycorrhizal fungi of Quercus falciparum in Shangyu beach, Zhejiang province were Russula and Tomentella (Wei et al., 2020). It can be seen that the main ectomycorrhizal fungi groups of different tree species and regions are different, which is closely related to the characteristics of tree species and environmental factors. Collectively, these studies indicated the diversity and composition of ectomycorrhizal fungi could be used as an important index for evaluating the restoration of soil functions (Pradhan et al., 2014; Pradhan et al., 2014).

\section{The relationships between soil characteristics and ectomycorrhizal fungal community}

Besides differences in host, abiotic conditions formed another important filter for ectomycorrhizal fungal communities. Soil fungal community plays an important role in biogeo-chemical cycles in ecosystems and can be significantly affected by environmental disturbances (Rosales-Castillo et al., 2018). The integration of soil biological indicators with chemical and physical indicators is an important factor in the evaluation of soil quality and the recovery process (Silva et al., 2018). Regarding the third results, the effects of environmental factor and host on pattern of ECM fungal community structure at the regional scale have been speculated in previous studies (e.g. Tedersoo et al., 2012; Wu et al., 2018). Acidification and increased $\mathrm{N}$ availability have a strong impact on ectomycorrhizal fungal community diversity, richness, and evenness (Toljander et al., 2006; Suz et al., 2014), while no similar findings were obtained in our study. As a result, soil TP and AP were the main factor effecting soil ectomycorrhizal fungal community diversity, especially Chao1 index, Observed_species, Pielou_e index, and Shannon index. 
Soil microbes should be considered drivers of productivity diversity in terrestrial ecosystems (van Der Heijden et al., 2008). In the process of vegetation restoration, soil fungal community was significantly affected by the changing soil properties (Cline and Zak, 2015), which in turn, were most likely affected by vegetation (Yao et al., 2018; Barnes et al., 2018). What's more, previous research also has already shown that soil pH is considered a most important factor in shaping soil ectomycorrhizal fungal community composition (Kutszegi et al., 2015; Matsuoka et al., 2016) and it was confirmed in our study. Soil pH can not only directly affect the community composition of ectomycorrhizal fungi, because the optimum $\mathrm{pH}$ value of ectomycorrhizal fungi is different, but also indirectly affect the community composition of ectomycorrhizal fungi by affecting nutrient availability (Erland and Taylor, 2002). While, some findings demonstrated that no significant influence of soil pH on soil microbial community-composition (Yu et al., 2020; Bastida et al., 2013). This may be due to the low sensitivity of fungi and the wide optimum range of soil conditions (Rousk et al., 2010), or the significant fluctuation of soil pH with vegetation restorations. Soil fungi perform important functions in nutrient cycling, while soil nutrients shape soil fungal communities with different functional groups (Perez-lzquierdo et al., 2017; Li et al., 2018). In our study, soil TC, TN, TP, AP had important roles in the soil fungal community, which was consistent with a previous large-scale research study (Schappe et al., 2020; Cai et al., 2018). It follows then that the differences in ectomycorrhizal fungal diversity and composition found between samplings could be attributed to the different revegetation types.

\section{Conclusion}

In conclusions, the current study has uncovered the distinct difference of soil characteristics and ectomycorrhizal fungal community composition in a typical Fe ore tailing in Liaoning. It is noteworthy that soil properties could be improved by different revegetation types, and RPL could significantly better improve soil nutrients than PKSZ and PSC. In addition, compared to PKSZ and PSC, RPL could better improve soil ectomycorrhizal fungal community diversity. Soil ectomycorrhizal fungal community composition significantly differed depending on revegetation types. Changes of soil nutrients caused by different revegetation types were key factors affecting the ectomycorrhizal fungal community diversity and composition. Thus, these results indicated that RPL might be a more suitable species for the revegetation of iron mine tailings.

\section{Declarations}

\section{Author contribution}

Wenxu Zhu: Sampling, measurement, data Analysis and writing-original draft

Changjun Ding: visualization, writing (review and editing) and funding acquisition

Keye Zhu: Data Analysis and writing-review and editing

Weixi Zhang: Data analysis and visualization 
Dejun Liang: Sampling and investigation

XiaoJiang Wang: Sampling and investigation

Aiping Li: Sampling and investigation

Xiaohua Su: Conceptualization, methodology, resources

Funding This work was supported by the Basic Research Fund of RIF (Grant No. CAFYBB2020SZ002, Grant No. CAFYBB2017ZA001-3), and The National Natural Science Foundation of China (Grant No.31870662).

Availability of data and materials The datasets used and analysed during the current study are available from the corresponding author on reasonable request.

Ethics approval and consent to participate Not applicable.

Consent for publication Not applicable.

Competing interests The authors declare no competing interests.

\section{References}

1. Araújo T, Freitas-Silva LD, Santana B, Kuki KN, Silva L (2015) Morphoanatomical responses induced by excess iron in roots of two tolerant grass species. Environ Sci Pollut R 22(3):2187-2195. doi: $10.1007 / \mathrm{s} 11356-014-3488-1$

2. Augé R, Toler HD, Moore JL, Cho K, Saxton AM (2007) Comparing contributions of soil versus root colonization to variations in stomatal behavior and soil drying in mycorrhizal sorghum bicolor and cucurbita pepo. J Plant Physiol 164(10):1289-1299. doi: 10.1016/j.jplph.2006.08.005

3. Barnes CJ, Gast C, Mcnamara NP, Rowe R, Bending GD (2018) Extreme rainfall affects assembly of the root-associated fungal community. New Phytol 220(4):1172-1184. doi: 10.1111/nph.14990

4. Bastida F, Hernández T, Albaladejo J, García C (2013) Phylogenetic and functional changes in the microbial community of long-term restored soils under semiarid climate. Soil Biol Biochem 65:1221. doi: $10.1016 /$ j.soilbio.2013.04.022

5. Caban JR, Kuppusamy S, Kim JH, Yoon YE, Kim SY, Lee YB (2018) Green manure amendment enhances microbial activity and diversity in antibiotic-contaminated soil. Appl Soil Ecol. doi: 10.1016/j.apsoil.2018.04.013

6. Cai ZQ, Zhang YH, Yang C, Wang S (2018) Land-use type strongly shapes community composition, but not always diversity of soil microbes in tropical china. CATENA 165:369-380. doi: 10.1016/j.catena.2018.02.018

7. Campos D, Mariana CR, Pearse, Stuart J, Eller, Cleiton B et al (2015) Mineral nutrition of campos rupestres plant species on contrasting nutrient-impoverished soil types. New Phytol 205(3):1183- 
1194. doi: $10.1111 / \mathrm{nph} .13175$

8. Chang z, Li C, Li, Lu h, Zhao et al (2019) Dynamics of storage and relative availability of soil inorganic nitrogen along revegetation chronosequence in the loess hilly region of china sciencedirect. Soil Till Res 187:11-20. doi: 10.1016/j.still.2018.11.006

9. Chanthorn W, Hartig F, Brockelman WY (2017) Structure and community composition in a tropical forest suggest a change of ecological processes during stand development. Forest Ecol Manag 404:100-107. doi: 10.1016/j.foreco.2017.08.001

10. Davidson EA, Françoise YI, Nepstad DC (2004) Effects of an experimental drought on soil emissions of carbon dioxide, methane, nitrous oxide, and nitric oxide in a moist tropical forest. Global Change Biol. doi: 10.1111/j.1365-2486.2004.00762.x

11. Deng J, Bai X, Zhou Y, Zhu W, Yin Y (2020a) Variations of soil microbial communities accompanied by different vegetation restoration in an open-cut iron mining area. Sci Total Environ 704:135243. doi: 10.1016/j.scitotenv.2019.135243

12. Deng J, Yin Y, Luo J, Zhu W, Zhou Y (2019b) Different revegetation types alter soil physical-chemical characteristics and fungal community in the baishilazi nature reserve. PeerJ 6:e6251. doi: $10.7717 /$ peerj. 6251

13. Deng J, Yin Y, Zhu W, Zhou Y (2020) Response of the soil environment factors and microbial communities to phytoremediation with Robinia pseudoacacia in an openãf1⁄2ut magnesite mine[J]. Land Degrad Dev. doi: 10.1002/Idr.3599

14. Deng J, Zhou Y, Bai X, Luo J, Zhu W (2019a) Soil microbial functional diversity responses to different revegetation types in baishilazi nature reserve. Pol J Environ Stud 28(5). doi: 10.15244/pjoes/99100

15. Dinesh R, Chaudhuri S, G (2013) Soil biochemical/microbial indices as ecological indicators of land use change in mangrove forests. Ecol Indic 32(32):253-258. doi: 10.1016/j.ecolind.2013.03.035

16. Erez-Izquierdo LP, Zabal-Aguirre M, Flores-Renter D, Alez-Mart S, Rinc A (2017) Functional outcomes of fungal community shifts driven by tree genotype and spatial-temporal factors in mediterranean pine forests. Environ Microbiol 19(4):1639-1652. doi: 10.1111/1462-2920.13690

17. Erland S, Taylor A (2002) Diversity of ecto-mycorrhizal fungal communities in relation to the abiotic environment. Springer Berlin Heidelberg 163-200. doi: 10.1007/978-3-540-38364-2_7

18. Fernández S, Poschenrieder C, Marcenò C, Gallego JR, Jiménez-Gámez D, Bueno A et al (2017) Phytoremediation capability of native plant species living on pb-zn and hg-as mining wastes in the cantabrian range, north of spain. J. Geochem. Explor 2016:S0375674216301182. doi: 10.1016/j.gexplo.2016.05.015

19. Fisseha A, Tamrat B, Emiru B (2016) The potential role of arbuscular mycorrhizal fungi in the restoration of degraded lands. Front. Microbiol 2016,7. doi: 10.3389/fmicb.2016.01095

20. Fitze D, Wiepning A, Kaldorf M, Ludwig-Müller J (2005) Auxins in the development of an arbuscular mycorrhizal symbiosis in maize. J Plant Physiol 162(11):1210-1219. doi:

10.1016/j.jplph.2005.01.014 
21. Gabriele C, Erica L, Enrico E, Francesco D, Maria G, Annamaria A et al (2017) The abundance and diversity of arbuscular mycorrhizal fungi are linked to the soil chemistry of screes and to slope in the alpic paleo-endemic berardia subacaulis. PLoS ONE 12(2):e0171866. doi: 10.1371/journal.pone.0171866

22. Gastauer M, Filho PS, Ramos SJ, Caldeira CF, Silva JR, Siqueira JO et al (2018) Mine land rehabilitation in brazil: goals and techniques in the context of legal requirements. Ambio doi: 10.1007/s13280-018-1053-8

23. Gong M, Tang M, Hui C, Zhang Q, Feng X (2013) Effects of two glomus species on the growth and physiological performance of sophora davidii seedlings under water stress. New Forest 44(3):399408. doi: 10.1007/s11056-012-9349-1

24. González-Alcaraz M, Gestel CV (2017) Changes in soluble metal concentrations induced by variable water table levels as response to liming and phragmites australis growth in metal-polluted wetland soils: management effectiveness. Geoderma 289:20-28. doi: 10.1016/j.geoderma.2016.11.019

25. Guo MS, Gao GL, Ding GD, Zhang Y, Zhao YY, Ren Y (2018) Diversity of ectomycorrhizal fungi associated with pinus sylvestris var. mongolica in hulunbuir sandy land. Mycosystema doi: 10.13346/j.mycosystema.180114

26. Heckenroth A, Rabier J, Dutoit T, Torre F, Prudent P, Laffont-Schwob I (2016) Selection of native plants with phytoremediation potential for highly contaminated mediterranean soil restoration: tools for a non-destructive and integrative approach. J Environ Manage 850-863. doi:

10.1016/j.jenvman.2016.09.029

27. Heijden M, Rdgett B, Straalen N (2010) The unseen majority: soil microbes as drivers of plant diversity and productivity in terrestrial ecosystems. Ecol Lett 11(3):296-310. doi: 10.1111/j.14610248.2007.01139.x

28. Hong X, Wei Q, Li M, Yu T, Yan Q, Hu Y (2021) Effects of aboveground and underground litter input on the dynamic balance of soil organic carbon in typical subtropical forests. Chin J Appl Ecol 32(3):11. doi:10.13287/J.1001-9332.202103.008

29. Hu PL, Liu SJ, Ye YY et al (2018) Effects of environmental factors on soil organic carbon under natural or managed vegetation restoration. Land Degrad Dev 29(3). doi:10.1002/ldr.2876

30. Jin W, Yang Y, Sun H, Chen L, Yuan Z (2020) Diversity of Ectomycorrhizal Fungi in the Oak Forest of Virginia. Forestry Science 56(1):13.. doi: CNKI:SUN:LYKE.0.2020-01-012

31. Juge $\mathrm{C}$, Cossette $\mathrm{N}$, Jeanne $\mathrm{T}$, Hogue $\mathrm{R}$ (2021) Long-term revegetation on iron mine tailings in northern Québec and Labrador and its effect on arbuscular mycorrhizal fungi. Appl Soil Ecol. doi: 10.1016/J.APSOIL.2021.104145

32. Krug VC, Anjos B, Leticia M, Adriana G, Luiz SS (2018) Microbiome of a revegetated iron-mining site and pristine ecosystems from the brazilian cerrado. Appl Soil Ecol. doi: 10.1016/j.apsoil.2018.07.011

33. Kutszegi G, Siller I, Dima B, Takács K, Péter (2015) dor. Drivers of macrofungal species composition in temperate forests, west hungary: functional groups compared. Fungal Ecol. 17,69-83. doi: 10.1016/j.funeco.2015.05.009 
34. Leal PL, Varón-López M, Isabelle GDOP, Jessé V, Fonsêca SS, Cláudio R, Siqueira JO et al (2016) Enrichment of arbuscular mycorrhizal fungi in a contaminated soil after rehabilitation. Braz $\mathrm{J}$ Microbiol 47(4):853-862. doi: 10.1016/j.bjm.2016.06.001

35. Li S, Shakoor A, Wubet T, Zhang N, Liang Y, Ma K (2018) Fine-scale variations of fungal community in a heterogeneous grassland in inner mongolia: effects of the plant community and edaphic parameters. Soil Biol Biochem 122:104-110. doi: 10.1016/j.soilbio.2018.04.007

36. Liu LL, Yao DL, Wen Y, Ke HU, Wang X (2009) Research on soil macro-animal community of ecological restoration and reconstruction in abandoned land of iron mine in anshan. Chin $\mathrm{J}$ Soil Sci 248-251. doi: 10.19336/j.cnki.trtb.2009.02.010

37. Lopez-Orenes A, Bueso MC, Conesa HM, Calderon AA, Ferrer MA (2017) Seasonal changes in antioxidative/oxidative profile of mining and non-mining populations of syrian beancaper as determined by soil conditions. Sci Total Environ 575(1):437-447. doi:

10.1016/j.scitotenv.2016.10.030

38. Louca S, Polz MF, Mazel F, Albright M, Huber JA, MI, O'Connor et al (2018) Function and functional redundancy in microbial systems. Nat Ecol Evol. doi: 10.1038/s41559-018-0519-1

39. Luo Y, Wu Y, Qiu J, Wang H, Yang L (2019) Suitability of four woody plant species for the phytostabilization of a zinc smelting slag site after 5 years of assisted revegetation. J Soil Sediment 19(2):702-715. doi: 10.1007/s11368-018-2082-4

40. Mahdavian K, Gjaderian SM, Torkzadeh-Mahani M (2017) Accumulation and phytoremediation of pb, zn, and ag by plants growing on koshk lead-zinc mining area, iran. J Soil Sediment 17(5):13101320. doi: $10.1007 / \mathrm{s} 11368-015-1260-x$

41. Matsuoka, Mori AS, Kawaguchi, Hobara (2016) and Osono. Disentangling the relative importance of host tree community, abiotic environment and spatial factors on ectomycorrhizal fungal assemblages along an elevation gradient. Fems Microiol. Ecol. 2016,92(5). doi: 10.1093/femsec/fiw044

42. Mendez MO, Neilson JW, Maier RM (2008) Characterization of a bacterial community in an abandoned semiarid lead-zinc mine tailing site. Appl Environ Microb 74(12). doi: 10.1128/AEM.02883-07

43. Molina R, Horton TR (2015) Mycorrhiza specificity: its role in the development and function of common mycelial networks. Springer Netherlands. doi: 10.1007/978-94-017-7395-9-1

44. Li MS (2006) Ecological restoration of mineland with particular reference to the metalliferous mine wasteland in china: a review of research and practice. Sci Total Environ. doi: 10.1016/j.scitotenv.2005.05.003

45. Munoz-Rojas M, Erickson TE, Martini D, Dixon KW, Merritt DJ (2016) Soil physicochemical and microbiological indicators of short, medium and long term post-fire recovery in semi-arid ecosystems. Ecol Indic 63:14-22. doi: 10.1016/j.ecolind.2015.11.038

46. Nottingham AT, Noah F, Turner BL, Jeanette W, Ostle NJ, Mcnamara NP et al (2018) Microbes follow humboldt: temperature drives plant soil microbial diversity patterns from the amazon to the andes. 
Ecology doi: 10.1002/ecy.2482

47. Omirou M, loannides IM, Ehaliotis C (2013) Mycorrhizal inoculation affects arbuscular mycorrhizal diversity in watermelon roots, but leads to improved colonization and plant response under water stress only. Appl Soil Ecol 63(1):112-119. doi: 10.1016/j.apsoil.2012.09.013

48. de Patricia D, Quadros K, Zhalnina et al (2016) Coal mining practices reduce the microbial biomass, richness and diversity of soil. Appl Soil Ecol. doi: 10.1016/j.apsoil.2015.10.016

49. Peng S, Yu K, Li Z, Wen Z, Zhang C (2019) Integrating potential natural vegetation and habitat suitability into revegetation programs for sustainable ecosystems under future climate change. Agr Forest Meteorol 269-270:270-284. doi: 10.1016/j.agrformet.2019.02.023

50. Pha B, Wei Z, Hca B, Dla B, Yuan Z, Jie Z et al (2021) Soil carbon accumulation with increasing temperature under both managed and natural vegetation restoration in calcareous soils. Sci Total Environ 767. doi: 10.1016/j.scitotenv.2021.145298

51. Pradhan M, Mishra M, Rath CC, Sukla LB (2014) Microbial Beneficiation of Iron Ore Collected from Rungta Mine Areas Using Aspergillus fumigatus

52. Prado I, Silva M, Prado D, Kemmelmeier K, Kasuya M (2019) Revegetation process increases the diversity of total and arbuscular mycorrhizal fungi in areas affected by the fundo dam failure in mariana, brazil. Appl Soil Ecol 141:84-95. doi: 10.1016/j.apsoil.2019.05.008

53. Rallage L, Liyanage M, Sulaiman C, Ismail MF, Hanafi MM (2021) Carbon mineralization dynamics of organic materials and their usage in the restoration of degraded tropical tea-growing soil. Agronomy 11(6):1-17. doi: 10.3390/agronomy 11061191

54. Rios CO, Siqueira-Silva Al, Pereira EG (2021) How does drought affect native grasses' photosynthesis on the revegetation of iron ore tailings? Environ Sci Pollut R 28(12):14797-14811. doi:

$10.1007 /$ s11356-020-11599-x

55. Rios C, Souza BD, Siqueira-Silva A, Pereira E (2017) Assessment of iron toxicity in tropical grasses with potential for revegetating mined areas. Pol J Environ Stud 26(5):2167-2173. doi: $10.15244 /$ pjoes/68429

56. Rosales-Castillo Jesús O, Ken, Vázquez-Garcidue MS, Rafael AR García-Oliva Felipe, and VázquezMarrufo Gerardo. (2017). Fungal community and ligninolytic enzyme activities in quercus deserticola trel.litter from forest fragments with increasing levels of disturbance. Forests9(1),11. doi: 10.3390/f9010011

57. Rosinger C, Sandén, Hans, Matthews B, Mayer M, Godbold D (2018) Patterns in ectomycorrhizal diversity, community composition, and exploration types in european beech, pine, and spruce forests. Forests 9(8). doi: 10.3390/f9080445

58. Rousk J, Bååth E, Brookes PC, Lauber CL, Lozupone C, Caporaso JG et al Soil bacterial and fungal communities across a ph gradient in an arable soil.ISME J. 4(10),1340-1351. doi:

10.1038/ismej.2010.58

59. Ruibal C, Gueidan C, Selbmann L, Gorbushina AA, Crous PW (2009) Phylogeny of rock-inhabiting fungi related to dothideomycetes. Stud Mycol 64(64):123-133. doi:10.3114/SIM.2009.64.06 
60. Saitta A, Anslan S, Bahram M, Brocca L, Tedersoo L (2018) Tree species identity and diversity drive fungal richness and community composition along an elevational gradient in a mediterranean ecosystem. Mycorrhiza 39-47. doi: 10.1007/s00572-017-0806-8

61. Santos T, Karl K, Nicoletti MM, Luiz SS, Carbone C, Souza MFMD (2017) Arbuscular mycorrhizal fungal communities in an iron mining area and its surroundings: inoculum potential, density, and diversity of spores related to soil properties. Cienc Agrotecnol 41(5):511-525. doi: 10.1590/141370542017415014617

62. Schappe T, Albornoz FE, Turner BL, Jones FA (2020) Co-occurring fungal functional groups respond differently to tree neighborhoods and soil properties across three tropical rainforests in Panama. Microb Ecol 79(3):675-685. doi: 10.1007/s00248-019-01446-z

63. Scheibe A, Seven, Jasmin, Gleixner, and Gerd, et al (2015) Effects of tree identity dominate over tree diversity on the soil microbial community structure. Soil Biol. Biochem. 219-227. doi: 10.1016/j.soilbio.2014.11.020

64. Schoch CL, Shoemaker RA, Seifert KA, Hambleton S, Spatafora JW, Crous PW (2006) A multigene phylogeny of the dothideomycetes using four nuclear loci. Mycologia 98(6):1041-1052. doi: 10.1080/15572536.2006.11832632

65. Sheoran V, Sheoran AS, Poonia P (2010) Soil reclamation of abandoned mine land by revegetation: a review Int. J Soil Sediment Wate 3(2):13

66. Siebielec S, Siebielec G, Stuczyński T, Sugier P, Grzdziel J (2018) Long term insight into biodiversity of a smelter wasteland reclaimed with biosolids and by-product lime. Sci Total Environ 636:10481057. doi: 10.1016/j.scitotenv.2018.04.372

67. Silva AO, Costa A, Teixeira AFDS, Guimares AA, Santos J, Moreira F (2018) Soil microbiological attributes indicate recovery of an iron mining area and of the biological quality of adjacent phytophysiognomies. Ecol Indic 93:142-151. doi: 10.1016/j.ecolind.2018.04.073

68. Silva GP, Fontes M, Costa L, Venegas VHA (2007) Potencialidade de plantas para revegetao de estéreis e rejeito da minerao de ferro da mina de alegria, mariana-mg. Pesquisa Agropecuária Tropical 36(3):165-172. doi: 10.5216/pat.v36i3.2038

69. Skirycz A, Castilho A, Chaparro C, Carvalho N, Tzotzos G, Siqueira JO (2014) Canga biodiversity, a matter of mining. Front Plant SCI 5(653):1. doi: 10.3389/fpls.2014.00653

70. Stavros D, Veresoglou L, Shaw J, Robin S (2011) Glomus intraradices and Gigaspora margarita arbuscular mycorrhizal associations differentially affect nitrogen and potassium nutrition of Plantago lanceolata in a low fertility dune soil. Plant Soil 340(s1-2):481-490. doi: 10.1007/s11104010-0619-4

71. Sugiyama Y, Matsuoka S, Osono T (2021) The ectomycorrhizal fungal communities react differently to climatic, edaphic and spatial variables depending on their host species. J Biogeogr 48(10). doi: $10.1111 /$ JBI.14220

72. Sun Y, Zhang Y, Feng W, Qin S, Fa K (2016) Effects of xeric shrubs on soil microbial communities in a desert in northern china. Plant Soil 414(1-2):1-14. doi: 10.1007/s11104-016-3111-y 
73. Suz LM, Barsoum N, Benham S, Dietrich HP, Fetzer KD, Fischer R et al (2015) Environmental drivers of ectomycorrhizal communities in europe's temperate oak forests. Mol Ecol 23(22):5628-5644. doi: $10.1111 / \mathrm{mec} .12947$

74. Tedersoo L, Bahram M, Toots M, Kõljalg U (2012) Towards global patterns in the diversity and community structure of ectomycorrhizal fungi. Mol Ecol 21(17):4160-4170. doi:10.1111/J.1365294X.2012.05602.X

75. Toljander J, Eberhardt JF, Paul YK, and LR, et al (2006) Species composition of an ectomycorrhizal fungal community along a local nutrient gradient in a boreal forest. New Phytol. 2006,170(4)(-),873883. doi: $10.2307 / 3694420$

76. Touce da -González A, Prieto-Fernández M, Giagnoni ARenellabG, andBrader bL et al (2017) Microbial community structure and activity in trace element-contaminated soils phytomanaged by gentle remediation options (gro) - sciencedirect. Environ Pollut 231:237-251. doi:

10.1016/j.envpol.2017.07.097

77. Urbanová M, Šnajdr J, Baldrian P (2015) Composition of fungal and bacterial communities in forest litter and soil is largely determined by dominant trees. Soil Biol Biochem 53. doi:

10.1016/j.soilbio.2015.02.011

78. van der Sietse L, Laura S, Orme M, David C, Thoms (2018) Environment and host as large-scale controls of ectomycorrhizal fungi. Nature 558(7709). doi: 10.1038/s41586-018-0189-9

79. Van D, Hartmann M (2016) Networking in the plant microbiome. Plos Biol 14(2):e1002378. doi: 10.1371/journal.pbio. 1002378

80. Wang L, Ji B, Hu Y, Liu R, Sun W (2017) A review on in situ phytoremediation of mine tailings. Chemosphere 184pp 594-600. doi: 10.1016/j.chemosphere.2017.06.025

81. Wang X, Guo, and LD (2012) Ectomycorrhizal fungus communities of quercus liaotungensis koidz of different ages in a northern china temperate forest. Mycorrhiza 2012,22(6)(-),461-470.. doi: $10.1007 / \mathrm{s} 00572-011-0423-\mathrm{x}$

82. Wei S, Song Y, Jia L, Yuan Z (2018) Diversity of ectomycorrhizal fungi of Quercus variabilis in the gneiss area of Taihang Mountains. Acta Mycologica Sinica 37(4):12. doi:

10.13346/j.mycosystema.170226

83. Wilson JD (2012) Chinese resource security policies and the restructuring of the asia-pacific iron ore market. Resour Policy 37(3). doi: 10.1016/j.resourpol.2012.03.002

84. Wu BW, Gao C, Chen L, Buscot F, Goldmann K, Purahong W et al (2018) Host phylogeny is a major determinant of fagaceae-associated ectomycorrhizal fungal community assembly at a regional scale. Front. Microbiol. 9. doi: 10.3389/fmicb.2018.02409

85. Wu S, Liu Y, Gordon S, Lachlan R, Ho CT, Cross AT et al (2018) Geochemical and mineralogical constraints in iron ore tailings limit soil formation for direct phytostabilization. Sci Total Environ 651:192-202. doi: 10.1016/j.scitotenv.2018.09.171

86. Wu S, You F, Wu Z, Bond P, Hall M, Huang L (2020) Molecular diversity of arbuscular mycorrhizal fungal communities across the gradient of alkaline fe ore tailings, revegetated waste rock to natural 
soil sites. Environ Sci Pollut R 27(11):11968-11979. doi: 10.1007/s11356-020-07780-x

87. Xue K, Nostrand JV, Vangronsveld J, Witters N, Janssen JO, Kumpiene J et al (2015) Management with willow short rotation coppice increase the functional gene diversity and functional activity of a heavy metal polluted soil. Chemosphere 138:469-477. doi: 10.1016/j.chemosphere.2015.06.062

88. Yao M, Rui J, Li J, Wang J, Cao W, Li X (2018) Soil bacterial community shifts driven by restoration time and steppe types in the degraded steppe of inner mongolia. CATENA 165:228-236. doi: 10.1016/j.catena.2018.02.006

89. Yu J, Liu F, Tripathi BM, Steinberger Y (2020) Changes in the composition of soil bacterial and fungal communities after revegetation with caragana microphylla in a desertified semiarid grassland. J Arid Environ 182:104262. doi: 10.1016/j.jaridenv.2020.104262

90. Yu J, Unc A, Zhang X, Steinberger Y (2016) Responses of the soil microbial catabolic profile and diversity to vegetation rehabilitation in degraded semiarid grassland. Appl Soil Ecol 101:124-131. doi: 10.1016/j.apsoil.2016.01.022

91. Zak, Donald R, Cline L, and C (2015) Soil microbial communities are shaped by plant-driven changes in resource availability during secondary succession. Ecology 96(12):3374-3385. doi: 10.1890/150184.1

92. Zhang A (2018) Study on ecological environment status and ecological restoration in fuxin mining area.Heilongjiang Environmental Journal89-92. doi:CNKI:SUN:HLJO.0.2018-04-026.

93. Zhang HL, Sun LN, Ma GF, Li TJ, Zheng XH (2018) Techniques for substrate amelioration and revegetation of iron mine wasteland in northern china. Chin J Ecol 37(10):3130-3136. doi: 10.13292/j.1000-4890.201810.008

94. Zhang H, Deng Q, Hui D, Wu J, Zhang D (2019) Recovery in soil carbon stock but reduction in carbon stabilization after 56-year forest restoration in degraded tropical lands. Forest Ecol Manag 441:1-8. doi: 10.1016/j.foreco.2019.03.037

95. Zhang J, Xu Y, Li F (2010) Plant growth and microbial community change in iron mine tailings during vegetation restoration. IEEE doi: 10.1109/ICBBE.2010.5516621

96. Zhang L (2014) GB, and Yamanaka. Soil properties in natural grassland, caragana korshinskii planted shrubland, and robinia pseudoacacia planted forest in gullies on the hilly loess plateau, china. CATENA 119,116-124. doi: 10.1016/j.catena.2014.03.016

\section{Figures}

\section{Figure 1}

Venn diagram. PKSZ: Pinus koraiensis Sieb. et Zucc., RPL: Robinia pseudoacacia L., PSC: Populus simonii Carr. 

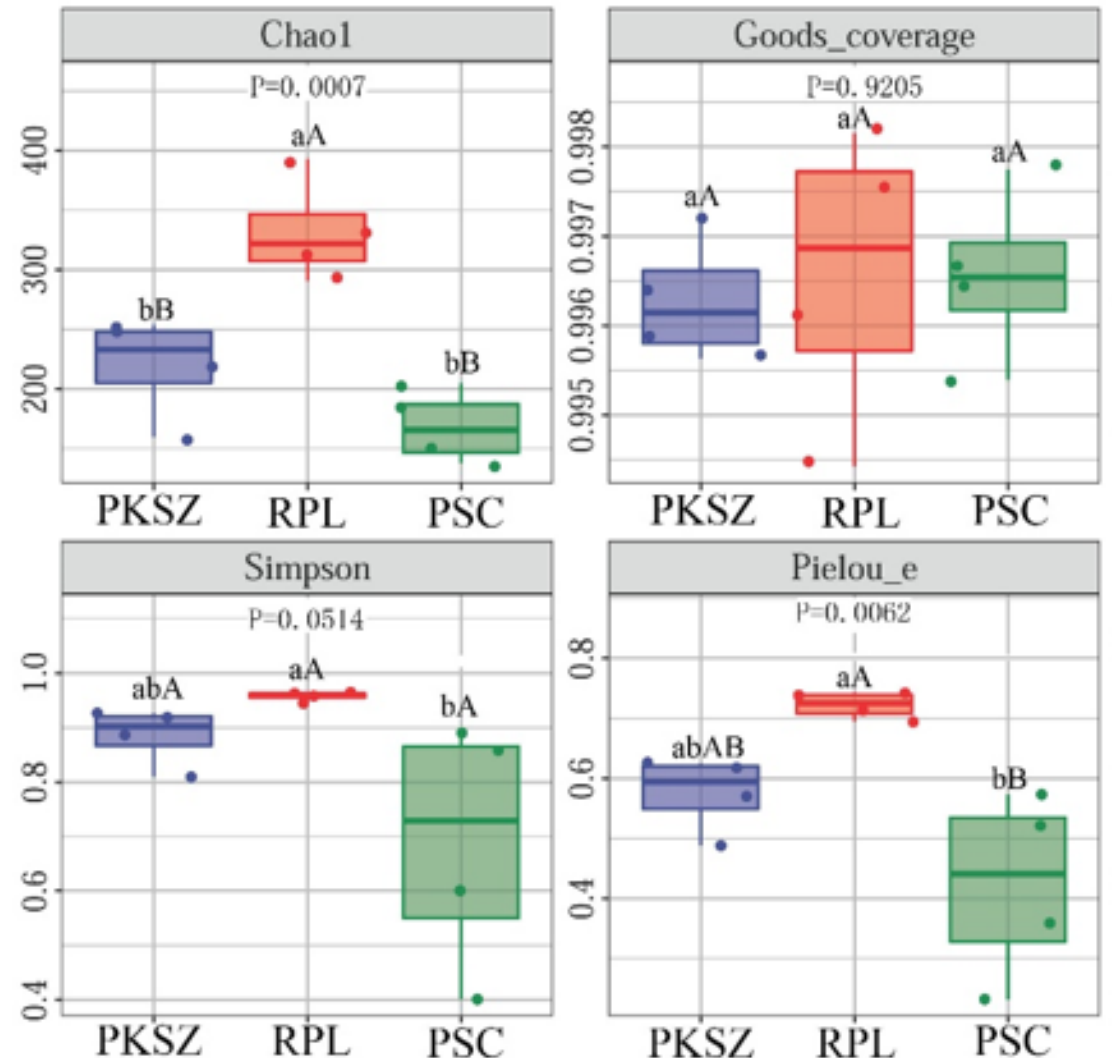

PKSZ RPL

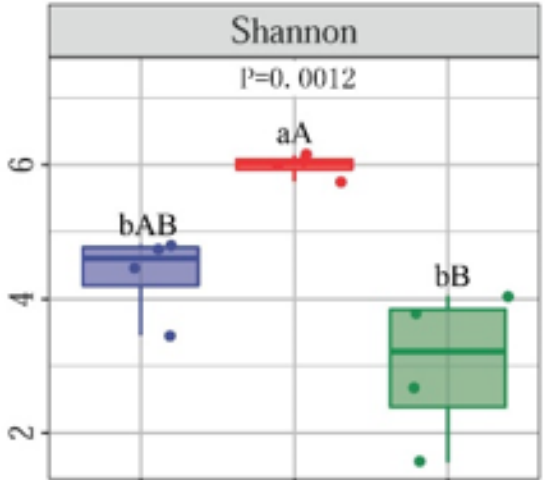

PKSZ RPL PŚ

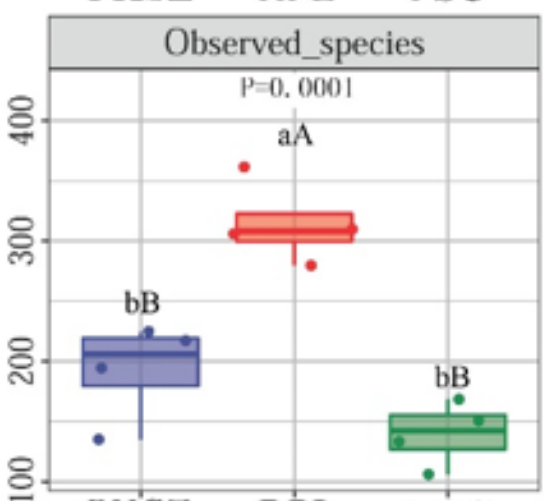

PKSZ RPL PSC
PKSZ

RPL

굴

\section{Figure 2}

Species richness, Simpson and Shannon diversity indices of AM fungal communities in roots of different native plant species inhabiting yet non-invaded or invaded plots on sites of five invasive plants, and significances of the effect of invasion status on these variables as revealed by the Westfall and Young multiple comparison method $(n=12)$. Significant $(P<0.05)$ results are highlighted in bold. PKSZ: Pinus koraiensis Sieb. et Zucc., RPL: Robinia pseudoacacia L., PSC: Populus simonii Carr. 


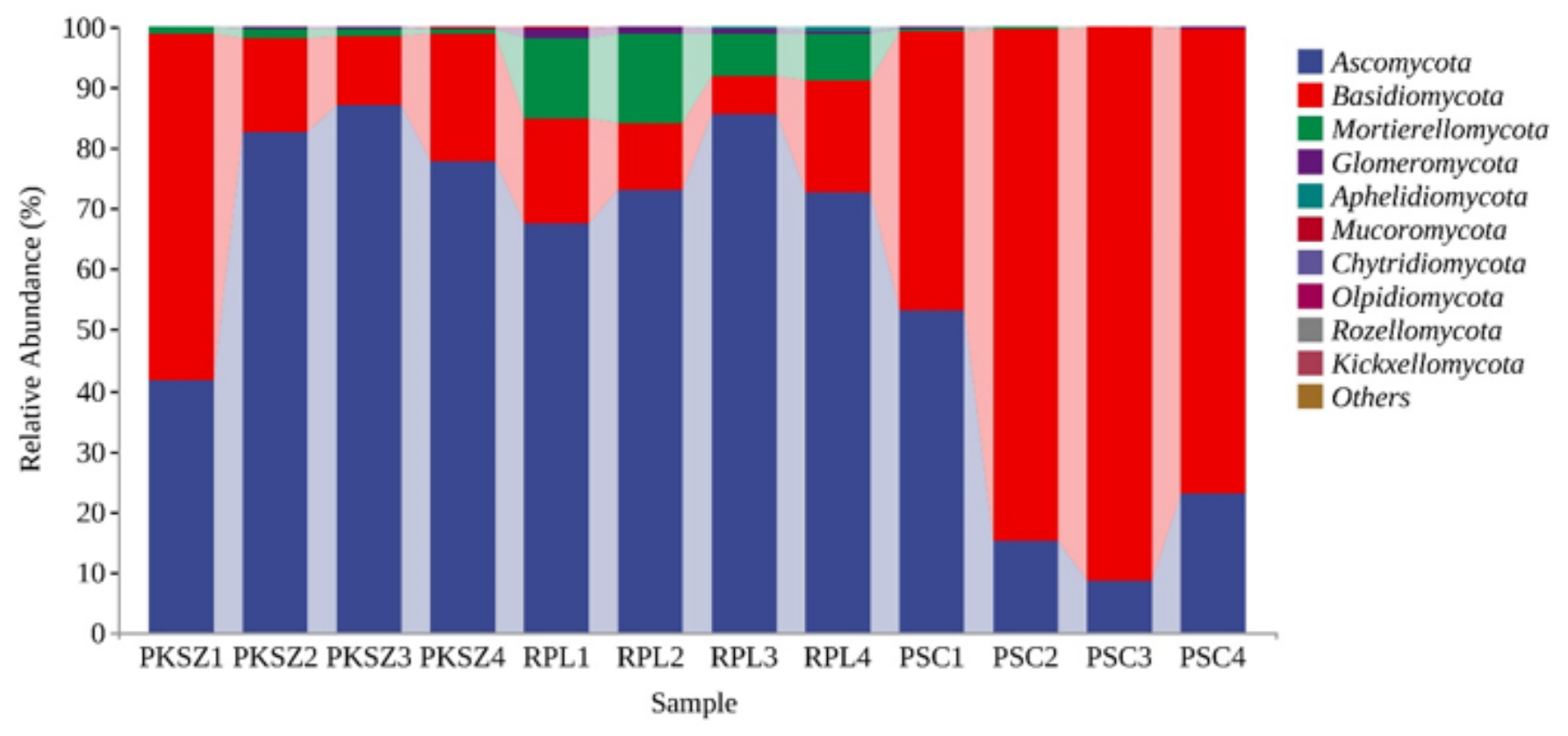

A

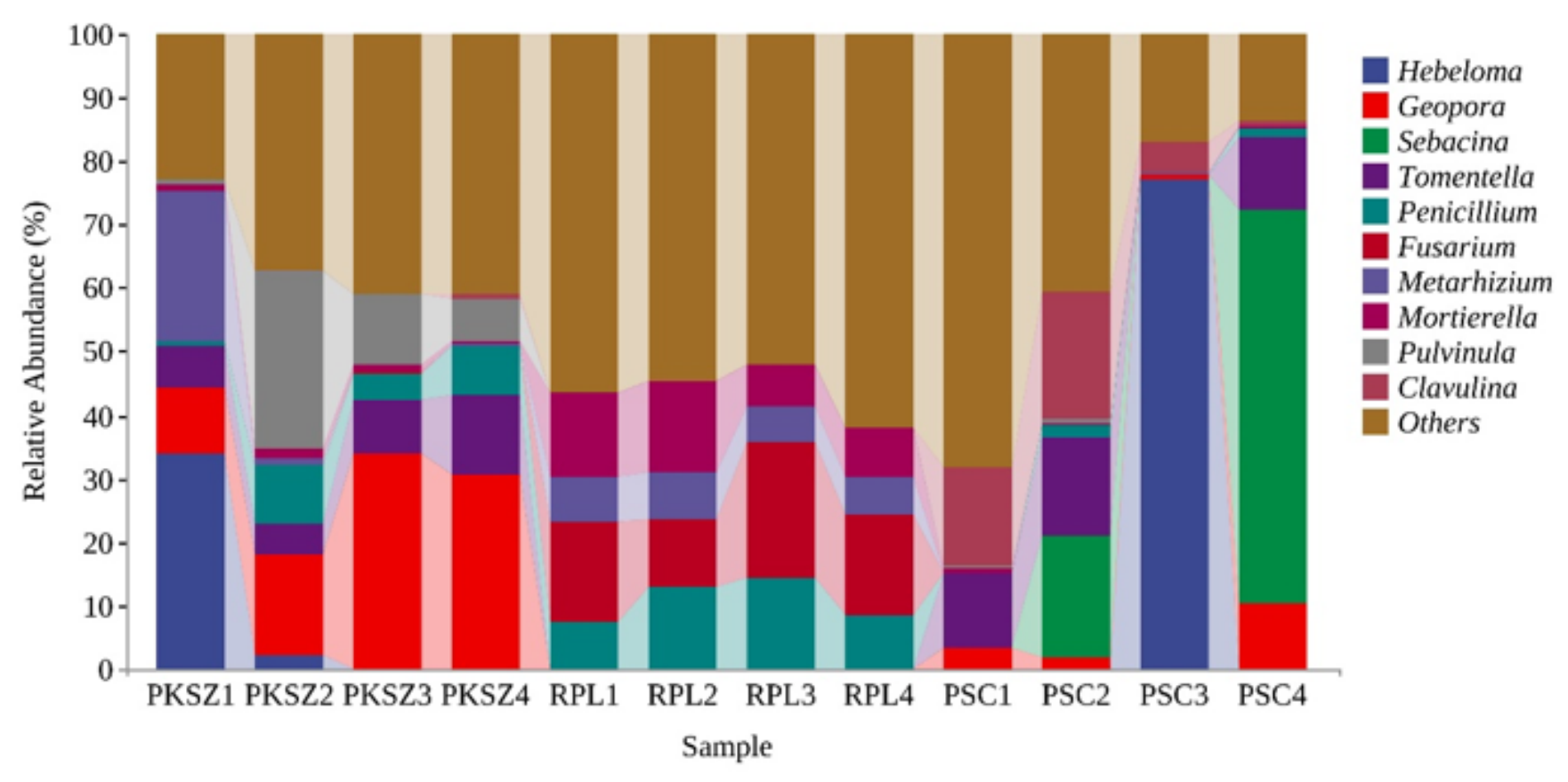

B

\section{Figure 3}

The relative abundance of ectomycorrhizal fungi at phylum (A) and genus (B) levels. PKSZ: Pinus koraiensis Sieb. et Zucc., RPL: Robinia pseudoacacia L., PSC: Populus simonii Carr. 
Least discriminant analysis (LDA) effect size taxonomic cladogram. PKSZ: Pinus koraiensis Sieb. et Zucc., RPL: Robinia pseudoacacia L., PSC: Populus simonii Carr.

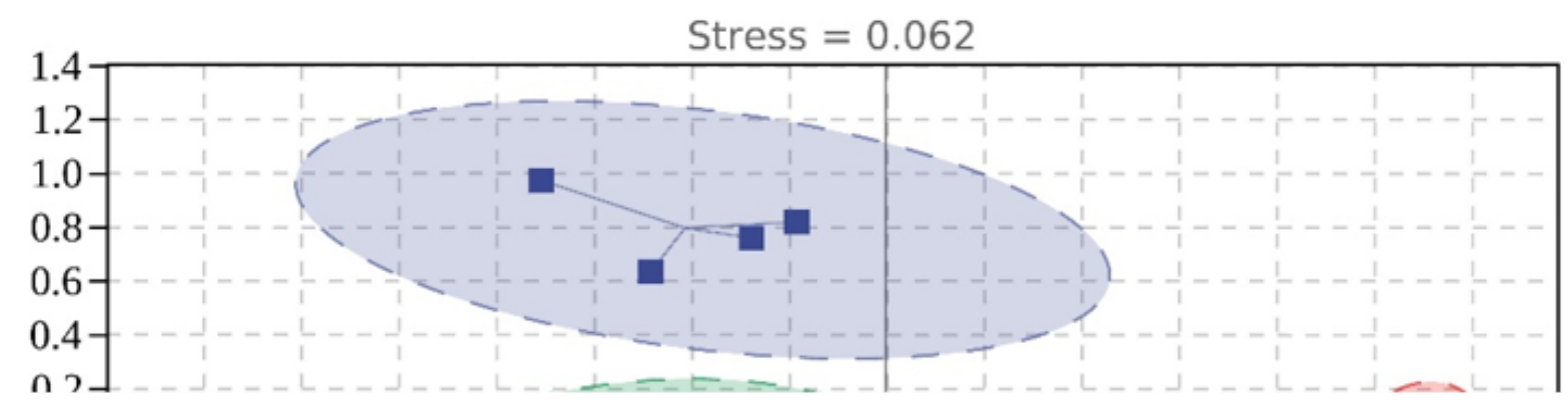

\section{Figure 5}

The ectomycorrhizal fungal beta diversity among different samples. PKSZ: Pinus koraiensis Sieb. et Zucc., RPL: Robinia pseudoacacia L., PSC: Populus simonii Carr. 

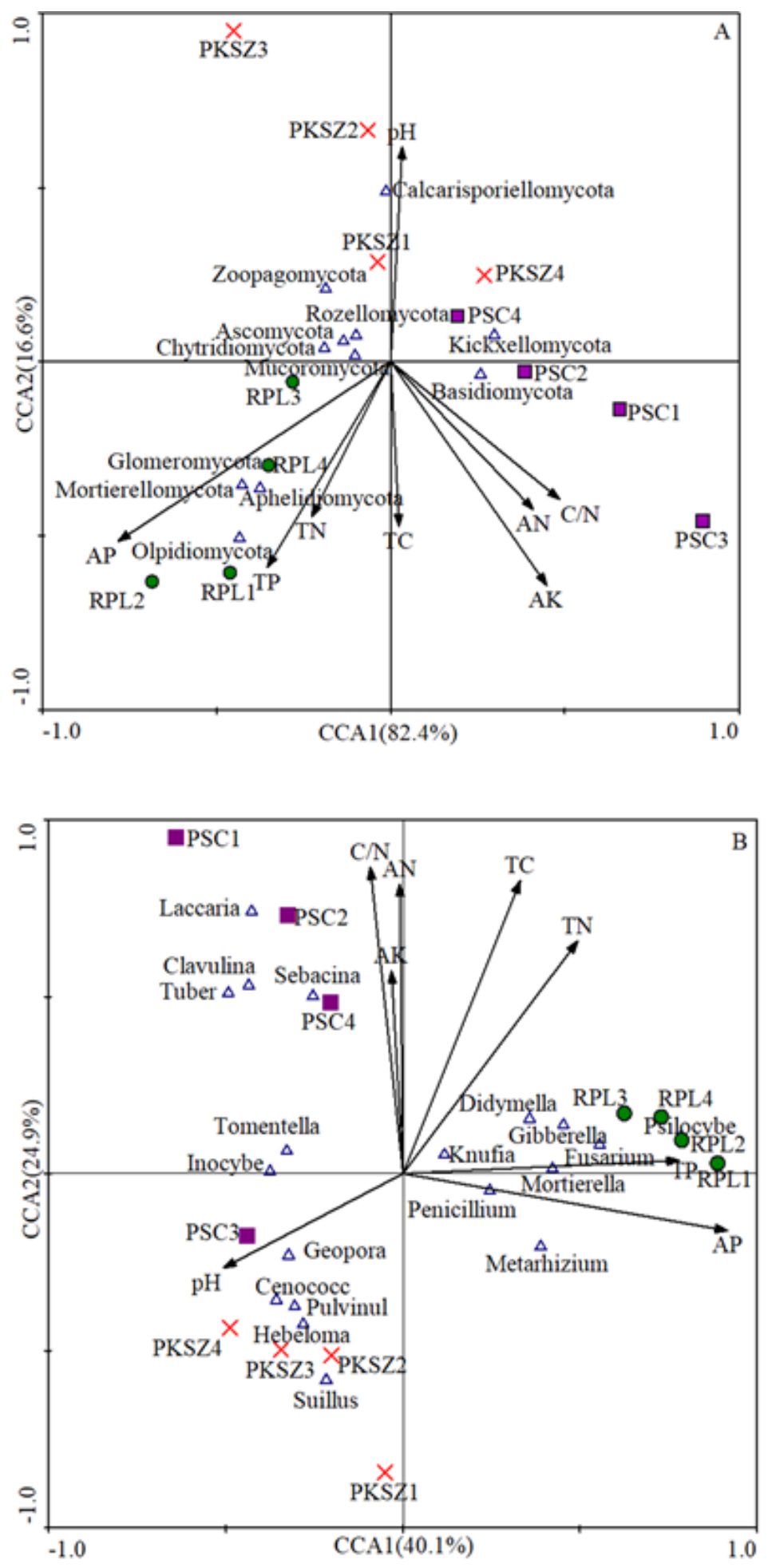

Figure 6

The contribution of soil basic to ectomycorrhizal fungal community composition at the phylum $(A)$ and genus (B) level. PKSZ: Pinus koraiensis Sieb. et Zucc., RPL: Robinia pseudoacacia L., PSC: Populus simonii Carr. TC: total carbon, TN: total nitrogen, $\mathrm{C} / \mathrm{N}$ : $\mathrm{C}$ to $\mathrm{N}$ ration, AN: available nitrogen, TP: total phosphorus, AP: available phosphorus, AK: available potassium. 


\section{Supplementary Files}

This is a list of supplementary files associated with this preprint. Click to download.

- Supplementmaterial.docx 